\title{
Realization of Target Yield in Bt Cotton (Gossypium hirsutum) with Different Methods of Establishment under Varied Dates of Planting
}

\author{
Prasanna S. Pyati", B.M. Chittapur, A.S. Halepyati, \\ U.K. Shanwad, S.N. Bhat and M.R. Umesh \\ Division of Agronomy, ICAR-NDRI, Karnal, 132001, Haryana, India \\ *Corresponding author
}

\author{
A B S T R A C T
}

\begin{tabular}{|l}
\hline K e y w o r d s \\
Dibbling, Growth, \\
NDVI, SPAD, Time \\
of planting, \\
Transplanting, Yield. \\
\hline Article Info \\
\hline $\begin{array}{l}\text { Accepted: } \\
\text { 24 September } 2017 \\
\text { Available Online: } \\
\text { 10 November } 2017\end{array}$
\end{tabular}

\section{Keywords} of planting,

Transplanting, Yield.

rticle Info

24 September 2017

10 November 2017
A field experiment was conducted at Agronomy Farm, College of Agriculture, University of Agricultural Sciences, Raichur, Karnataka with the objective to know how long target yields in $B t$ cotton could be achieved in the TBP irrigation command. Cotton seeds dibbled or seedlings transplanted during $1^{\text {st }}$ and $2^{\text {nd }}$ fortnights of June and July and $1^{\text {st }}$ fortnight of August using a split plot design. Transplanting of seedlings $\left(3457 \mathrm{~kg} \mathrm{ha}^{-1}\right)$ out yielded seed dibbling (3280 kg ha ${ }^{-1}$ ) and the difference widened with delay in planting (50 kg to $266 \mathrm{~kg}$ $\mathrm{ha}^{-1}$ ). Among all, June $1^{\text {st }}$ fortnight transplanted crop produced significantly higher seed cotton yield (4426 kg ha ${ }^{-1}$ ) followed by dibbled crop during the same period (4376 kg ha-1) owing to better growth. Yield decreased by $967 \mathrm{~kg}$ to $1042 \mathrm{~kg} \mathrm{ha}^{-1}$ with July $1^{\text {st }}$ fortnight over June $2^{\text {nd }}$ fortnight planting with dibbling and transplanting, respectively. August $1^{\text {st }}$ fortnight planted crop recorded the lowest yields (1640 and $1906 \mathrm{~kg} \mathrm{ha}^{-1}$ with dibbling and transplanting, respectively) among all. Thus, time of planting appeared more critical than method of planting.

\section{Introduction}

Karnataka, in India ranks fifth in area, fourth in production and fifth in productivity among the cotton growing states. Bt cotton is intensively cultivated in the North Eastern Dry Zone and Northern Dry Zone of the state (Zone 2 and 3) covering partly the Tungabhadra and Upper Krishna (TBP and UKP) irrigation Commands on black soil. The area under this crop in these commands has been increasing distinctly over the past half a decade. The average yields which hovered around 4.0 to $5.0 \mathrm{t} \mathrm{ha}^{-1}$ initially with the advent of $B t$ cultivars of late are either remaining stagnant of declining which is a deterrent to the farmers due to squeezing returns and hence needs special attention. In the Northern Karnataka region, there are several reasons for the low yields in cotton such as imbalanced fertilizers application, late planting, and improper pest management etc. where the rainy season starts probably during second fortnight of June to as late as August.

Therefore, there is very large yield gap between the average productivity of the country and of the region under the study. In this context, there is need for efforts to achieve pre-set yield targets with balanced fertilization and appropriate method of planting. 
Transplanting, which was found promising in cotton in UKP irrigation project (Salakinkop, 2011and Honnali and Chittapur, 2013) was hypothesized to make good the yield losses caused due to late planting as a month old seedlings are used for planting and these seedlings could pick up their growth from where they have stopped in the nursery. Hence, the present study on impact of method of establishment and time of planting was envisaged in the Tunga Bhadra irrigation command on vertisols.

\section{Materials and Methods}

On-station field study was conducted during kharif 2015 in Agronomy Farm, University of Agricultural Sciences, Raichur, Karnataka, India. The soils are alkaline ( $\mathrm{pH} 8.2)$, nonsaline (EC $0.24 \mathrm{dS} / \mathrm{m}$ ), medium in organic Carbon (0.62 \%), low in available $\mathrm{N}(220 \mathrm{~kg}$ $\left.\mathrm{ha}^{-1}\right)$, medium in $\mathrm{P}_{2} \mathrm{O}_{5}\left(31 \mathrm{~kg} \mathrm{ha}^{-1}\right)$ and high in $\mathrm{K}_{2} \mathrm{O}\left(283 \mathrm{~kg} \mathrm{ha}^{-1}\right)$.

Fertilizer $\mathrm{N}, \mathrm{P}$ and $\mathrm{K}$ requirements were calculated by accounting the indigenous nutrient supply for a yield target of $5 \mathrm{t} \mathrm{ha}^{-1}$ (400:140:142.5 $\mathrm{N}: \mathrm{P}_{2} \mathrm{O}_{5}: \mathrm{K}_{2} \mathrm{O} \quad \mathrm{kg} \mathrm{ha}^{-1}$ ) and nutrient demand per ton of cotton lint yield as per set procedures of International Plant Nutrition Institute.

Ten treatments consisted of transplanting and dibbling of cv. Jaadhu at five dates of planting viz., $1^{\text {st }}$ and $2^{\text {nd }}$ fortnights of June and July and $1^{\text {st }}$ fortnight of August were laid out using Split plot design with three replications with a gross plot of $9 \mathrm{~m} \mathrm{x} 6 \mathrm{~m}$ and spacing of $90 \mathrm{~cm}$ $\mathrm{X} 60 \mathrm{~cm}$. Entire phosphorus and 50 per cent $\mathrm{N}$ and $\mathrm{K}$ were applied basally. Remaining $\mathrm{N}$ and $\mathrm{K}$ were applied twice at 45 and 75 days after planting. Prophylactic plant protection measures were taken up as and when pest and disease crossed ETL. Growth and yield attributes were recorded, analysed and interpreted.

\section{Results and Discussion}

2015 being dry year and due to outbreak of American pink bollworm in spite of prophylactic measures neither with planting technique nor with time of planting target yield was achieved.

Of the two methods of establishment, transplanting recorded higher yields $(3457 \mathrm{~kg}$ $\mathrm{ha}^{-1}$ ) than seed dibbling (3280 $\left.\mathrm{kg} \mathrm{ha}^{-1}\right)$ (Table 2 ), however, it was hardly by about $5.3 \%$. Results are in line with Honnali and Chittapur (2013). Nevertheless, the differences were more conspicuous with time of planting, reductions ranged from $2.3 \%$ with $2^{\text {nd }}$ fortnight of June to 19 and $63 \%$, respectively with $1^{\text {st }}$ and $2^{\text {nd }}$ fortnight of July and to a maximum of $148 \%$ with $1^{\text {st }}$ fortnight of August planting over planting during $1^{\text {st }}$ fortnight of June (4401 $\left.\mathrm{kg} \mathrm{ha}^{-1}\right)$. In all, transplanting during $1^{\text {st }}$ fortnight of June followed by dibbling at the same time fared better and transplanting during $2^{\text {nd }}$ fortnight of June was on par. The lowest yields were recorded with last planting particularly with dibbling (1906 and $1640 \mathrm{~kg} \mathrm{ha}^{-1}$, respectively) (Fig. 1).

Higher kapas yields with early planting (June planting) irrespective of method of planting could be attributed to seed cotton yield per plant (272.67 and $238.33 \mathrm{~g} /$ plant), boll weight per plant (5.71 and $5.19 \mathrm{~g} / \mathrm{boll})$, seed index (11.67 and 10.63), harvest index (0.46 and 0.45), and good opened bolls per plant at harvest (44.93 and 43.80 respectively with transplanting and dibbling during $1^{\text {st }}$ fort night of June) (Table 2).

The results are in line with Iqbal et al., (2012), Zaheer et al., (2014) and Rajesh Kumar et al., (2014). Elayan et al., (2015) reported a yield increase of 29 per cent with early planting ( $3^{\text {rd }}$ week of May) over delayed planting $\left(2^{\text {nd }}\right.$ week of June). 
Table.1 Growth parameters of Bt-Cotton as influenced by methods and dates of planting

\begin{tabular}{|c|c|c|c|c|c|c|c|}
\hline Treatments & $\begin{array}{l}\text { Plant } \\
\text { height } \\
(\mathrm{cm})\end{array}$ & $\begin{array}{c}\text { Mono./ } \\
\text { plant }\end{array}$ & $\begin{array}{l}\text { Sym. / } \\
\text { plant }\end{array}$ & $\begin{array}{l}\text { Leaf } \\
\text { area / } \\
\text { plant } \\
\left(\mathrm{dm}^{2}\right)\end{array}$ & $\begin{array}{l}\text { Leaf } \\
\text { area } \\
\text { index }\end{array}$ & $\begin{array}{c}\text { SPAD } \\
\text { reading at } \\
90 \\
\text { DAS/DAT }\end{array}$ & $\begin{array}{c}\text { NDVI } \\
\text { values at } \\
90 \\
\text { DAS/DAT }\end{array}$ \\
\hline \multicolumn{8}{|l|}{ Method of planting } \\
\hline Dibbling & 138 & 2.01 & 37.03 & 122.05 & 2.28 & 44.03 & 0.72 \\
\hline Transplanting & 149 & 2.23 & 39.81 & 124.64 & 2.33 & 46.36 & 0.80 \\
\hline S. Em. \pm & 1.06 & 0.03 & 0.12 & 0.26 & 0.01 & 0.18 & 0.01 \\
\hline C. D. @ 5\% & 6.95 & 0.16 & 0.80 & 1.69 & 0.03 & 1.15 & 0.05 \\
\hline \multicolumn{8}{|l|}{ Dates of planting } \\
\hline $1^{\text {st }} \mathrm{FN}$ of June & 179 & 2.57 & 42.54 & 135.49 & 2.52 & 49.89 & 0.81 \\
\hline $2^{\text {nd }} \mathrm{FN}$ of June & 163 & 2.33 & 39.65 & 132.74 & 2.46 & 47.86 & 0.80 \\
\hline $1^{\text {st }}$ FN of July & 145 & 2.07 & 39.02 & 121.18 & 2.33 & 45.08 & 0.77 \\
\hline $2^{\text {nd }} \mathrm{FN}$ of July & 127 & 1.87 & 35.98 & 116.13 & 2.16 & 42.35 & 0.73 \\
\hline $1^{\text {st }} \mathrm{FN}$ of August & 103 & 1.77 & 34.90 & 111.18 & 2.06 & 40.80 & 0.68 \\
\hline S. Em. \pm & 1.28 & 0.08 & 0.29 & 0.73 & 0.02 & 0.43 & 0.01 \\
\hline C. D. @ 5\% & 3.86 & 0.24 & 0.88 & 2.21 & 0.07 & 1.31 & 0.03 \\
\hline \multicolumn{8}{|c|}{ Interaction between method and dates of planting } \\
\hline Dibbling $-1^{\text {st }} \mathrm{FN}$ of June & 171 & 2.47 & 40.46 & 133.50 & 2.47 & 48.24 & 0.78 \\
\hline Dibbling $-2^{\text {nd }} F N$ of June & 162 & 2.07 & 38.75 & 130.82 & 2.42 & 46.76 & 0.77 \\
\hline Dibbling $-1^{\text {st }}$ FN of July & 140 & 2.00 & 37.81 & 121.17 & 2.31 & 43.50 & 0.72 \\
\hline Dibbling $-2^{\text {nd }} F N$ of July & 120 & 1.80 & 34.47 & 114.33 & 2.14 & 41.55 & 0.69 \\
\hline Dibbling $-1^{\text {st }} \mathrm{FN}$ of August & 95 & 1.73 & 33.65 & 110.43 & 2.05 & 40.12 & 0.62 \\
\hline Transplanting $-1^{\text {st }}$ FN of June & 186 & 2.67 & 44.61 & 137.48 & 2.56 & 51.55 & 0.84 \\
\hline Transplanting $-2^{\text {nd }} F N$ of June & 164 & 2.60 & 40.56 & 134.65 & 2.49 & 48.97 & 0.82 \\
\hline Transplanting $-1^{\text {st }}$ FN of July & 150 & 2.13 & 40.23 & 121.19 & 2.35 & 46.66 & 0.81 \\
\hline Transplanting $-2^{\text {nd }} F N$ of July & 134 & 1.93 & 38.31 & 117.94 & 2.18 & 43.15 & 0.76 \\
\hline Transplanting $-1^{\text {st }} \mathrm{FN}$ of August & 110 & 1.80 & 35.33 & 111.94 & 2.07 & 41.48 & 0.74 \\
\hline S. Em. \pm & 1.93 & 0.10 & 0.39 & 0.96 & 0.03 & 0.57 & 0.57 \\
\hline C. D. @ 5\% & 8 & NS & 1.31 & NS & NS & NS & NS \\
\hline
\end{tabular}


Table.2 Yield and yield attributes of Bt-cotton as influenced by methods and dates of planting

\begin{tabular}{|c|c|c|c|c|c|c|}
\hline Treatments & $\begin{array}{l}\text { Bolls/ } \\
\text { plant }\end{array}$ & $\begin{array}{c}\text { Boll } \\
\text { weight } \\
(\mathrm{g})\end{array}$ & $\begin{array}{c}\text { Seed cotton } \\
\text { yield } \\
\text { (g/plant) }\end{array}$ & $\begin{array}{c}\text { Seed cotton } \\
\text { yield } \\
(\mathrm{kg} / \mathrm{ha})\end{array}$ & $\begin{array}{l}\text { Seed } \\
\text { index }\end{array}$ & $\begin{array}{c}\text { Harvest } \\
\text { index }\end{array}$ \\
\hline \multicolumn{7}{|l|}{ Method of planting } \\
\hline Dibbling & 36.85 & 4.62 & 178.40 & 3280 & 9.24 & 0.36 \\
\hline Transplanting & 39.88 & 5.09 & 205.11 & 3457 & 9.76 & 0.37 \\
\hline S. Em. \pm & 0.19 & 0.07 & 2.54 & 19.60 & 0.07 & 0.00 \\
\hline C.D. @ 5\% & 1.27 & 0.42 & 16.63 & 128.41 & 0.44 & 0.01 \\
\hline \multicolumn{7}{|l|}{ Dates of planting } \\
\hline $1^{\mathrm{st}} \mathrm{FN}$ of June & 44.37 & 5.45 & 255.50 & 4401 & 11.15 & 0.46 \\
\hline $2^{\text {nd }} \mathrm{FN}$ of June & 43.10 & 5.14 & 232.28 & 4277 & 10.08 & 0.44 \\
\hline $1^{\text {st }} \mathrm{FN}$ of July & 38.87 & 4.80 & 210.50 & 3698 & 9.60 & 0.41 \\
\hline $2^{\text {nd }} \mathrm{FN}$ of July & 35.70 & 4.50 & 158.33 & 2693 & 8.38 & 0.32 \\
\hline $1^{\mathrm{st}} \mathrm{FN}$ of August & 29.80 & 4.38 & 102.17 & 1773 & 8.28 & 0.21 \\
\hline S. Em. \pm & 0.35 & 0.08 & 3.99 & 41 & 0.07 & 0.01 \\
\hline C.D. @ 5\% & 1.04 & 0.24 & 12.07 & 124 & 0.21 & 0.02 \\
\hline \multicolumn{7}{|c|}{ Interaction between method and dates of planting } \\
\hline Dibbling $-1^{\mathrm{st}} \mathrm{FN}$ of June & 43.80 & 5.19 & 238.33 & 4376 & 10.63 & 0.45 \\
\hline Dibbling $-2^{\text {nd }} F N$ of June & 42.27 & 5.00 & 220.67 & 4198 & 9.89 & 0.44 \\
\hline Dibbling $-1^{\text {st }} \mathrm{FN}$ of July & 36.07 & 4.59 & 199.33 & 3576 & 9.35 & 0.40 \\
\hline Dibbling $-2^{\text {nd }} F N$ of July & 33.27 & 4.24 & 146.00 & 2609 & 8.20 & 0.31 \\
\hline Dibbling $-1^{\text {st }} \mathrm{FN}$ of August & 28.87 & 4.07 & 87.67 & 1640 & 8.07 & 0.19 \\
\hline Transplanting - $1^{\text {st }} \mathrm{FN}$ of June & 44.93 & 5.71 & 272.67 & 4426 & 11.67 & 0.46 \\
\hline Transplanting $-2^{\text {nd }} F N$ of June & 43.93 & 5.28 & 243.90 & 4356 & 10.27 & 0.44 \\
\hline Transplanting $-1^{\text {st }}$ FN of July & 41.67 & 5.01 & 221.67 & 3819 & 9.85 & 0.41 \\
\hline Transplanting $-2^{\text {nd }} F N$ of July & 38.13 & 4.76 & 170.67 & 2777 & 8.56 & 0.32 \\
\hline Transplanting $-1^{\text {st }} \mathrm{FN}$ of August & 30.73 & 4.70 & 116.67 & 1906 & 8.49 & 0.23 \\
\hline S. Em. \pm & 0.48 & 0.12 & 5.05 & 55 & 0.11 & 0.01 \\
\hline C.D. @ 5\% & 1.72 & NS & NS & 197 & 0.47 & NS \\
\hline
\end{tabular}


Fig.1 Yield response curve of $B t$ Cotton under different methods and dates of planting

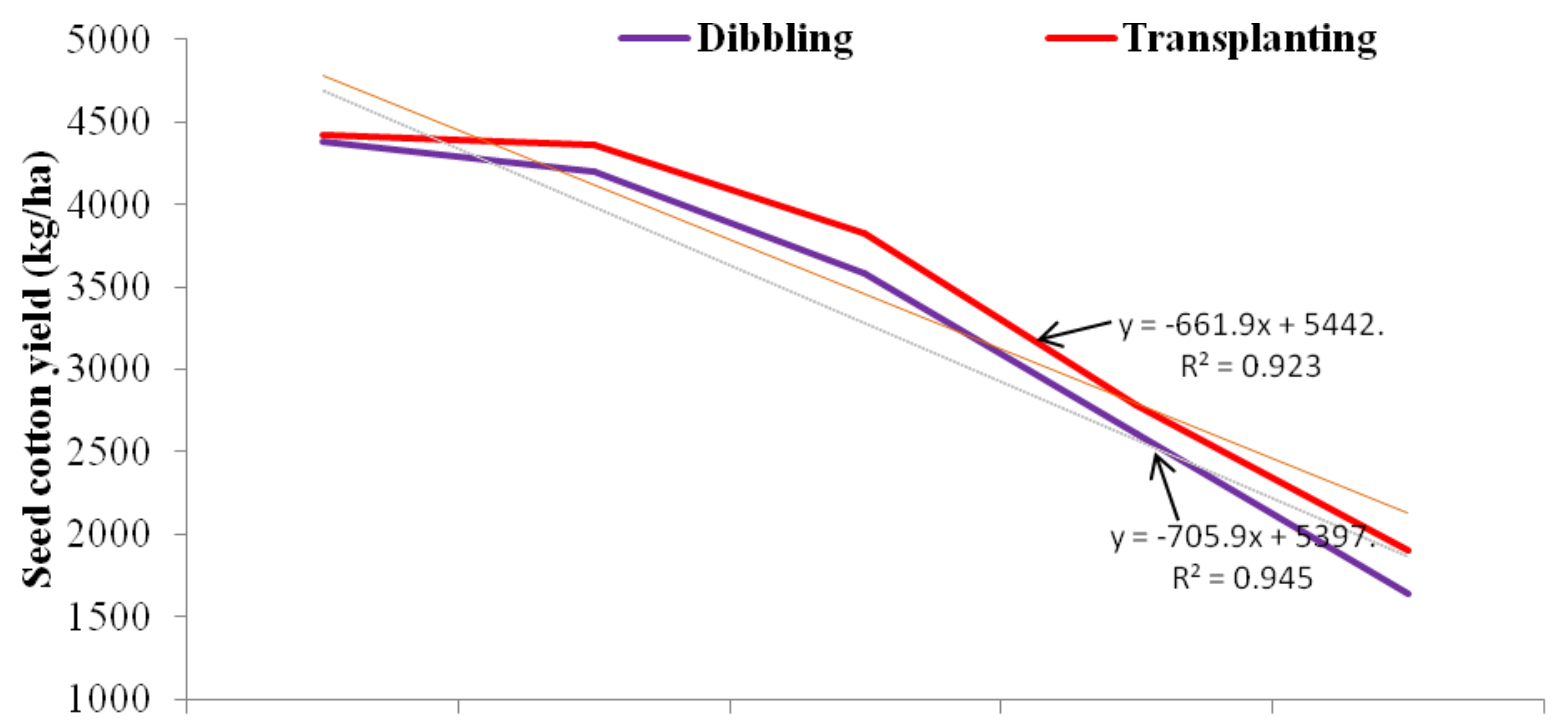

1stFN of June 2 nd FN of June 1st FN of July 2 nd FN of July 1st FN of August Dates of planting

These variations in yield components could be further traced back to improved plant growth and architecture viz., plant height $(186.2, \quad 171.3 \mathrm{~cm}$, respectively with transplanting and dibbling during $1^{\text {st }}$ fortnight of June), number of monopodials per plant (2.67 and 2.47, respectively with transplanting and dibbling during $1^{\text {st }}$ fortnight of June) and number of sympodials per plant (44.61 and 40.46, respectively with transplanting and dibbling during $1^{\text {st }}$ fortnight of June) which enabled better net radiation assimilation as evidenced by leaf area (137.48 $\mathrm{dm}^{2} /$ plant with transplanting and 133.5 $\mathrm{dm}^{2} /$ plant with dibbling during $1^{\text {st }}$ fortnight of June as against $111.94 \mathrm{dm}^{2} /$ plant with transplanting and $110.43 \mathrm{dm}^{2} /$ plant with dibbling, respectively during $1^{\text {st }}$ fortnight of August), leaf area index (2.56 with transplanting and 2.47 with dibbling, during $1^{\text {st }}$ fortnight of June as against 2.07 with transplanting and 2.05 with dibbling with during $1^{\text {st }}$ fortnight of August), SPAD (51.82, $51.55,47.54$ and 44.61 with transplanting and $47.51,48.24,45.47$ and 40.46 with dibbling, respectively at 45, 90 and 135 DAS/DAT, and at harvest during $1^{\text {st }}$ fortnight of June as against 42.08, 41.48, 37.31 and 35.33 with transplanting and 38.74, 40.12, 36.84 and 33.65 with dibbling, respectively at 45,90 and $135 \mathrm{DAS} / \mathrm{DAT}$ and at harvest during $1^{\text {st }}$ fortnight of August), and NDVI (0.82, 0.84, 0.81 and 0.80 with transplanting and 0.79 , $0.78, \quad 0.77$ and 0.76 with dibbling, respectively at 45, 90 and 135 DAS/DAT, and at harvest during $1^{\text {st }}$ fortnight of June as against $0.71,0.74,0.73$ and 0.67 with transplanting and $0.74,0.62,0.61$ and 0.61 with dibbling, respectively at 45, 90 and 135 DAS/DAT, and at harvest during $1^{\text {st }}$ fortnight of August) values which were higher with June planted crop whether dibbled or transplanted while last planted crop had the lowest values for all these attributes.

It was clear from the study that delayed planting would lead to yield reduction in spite of applying major nutrients in required quantities for targeted yields and planting methods would not help in recovering the yield losses though transplanting marginally fared better than dibbling. 


\section{References}

Elayan E. D., Sohair, Abdalla, A. M. A., Abdel Gawad, 2015, Effect of delaying planting date on yield, fiber and yarn quality properties in some cultivars and promising crosses of Egyptian cotton. American-Eurasian J. Agric. Environ. Sci., 15 (5): 754-763.

Honnali, S. N. and Chittapur, B. M., 2013, Enhancing Bt Cotton (Gossypium spp.) productivity through transplanting in Upper Krishna Project (UKP) command area of Karnataka. Indian J. Agron., 58 (1):105-108.

Iqbal, J., Wajid, S. A., Ahmad, A. and Arshad, M., 2012, Comparative studies on seed cotton yield in relation to planting dates under diverse agroenvironment of Punjab. Pakistan $J$.
Agric. Sci., 64(1): 59-63.

Rajesh Kumar, Bhattoo, M. S., Punia, S. S., Nabin. and Satbeer Yadav, 2014, Performance of different Bt cotton (Gossypium hirsutum L.) hybrids under varying dates of planting. J. cotton Res. Dev., 20(2):263-264.

Salakinkop S R., 201. Enhancing the productivity of irrigated $B t$ cotton (Gossypium hirsutum) by transplanting and planting geometry. Indian $J$. of Agril. Sci., 81 (2):150-3.

Zaheer, A. D., Shamshuddin, T., Qammaruddin and Chand, F. O., 2014, Impact of planting dates and picking stages on yield and seed maturity of cotton (Gossypium hirsutum L.) varieties. Sarhad J. Agri., 30(4): 404410.

\section{How to cite this article:}

Prasanna S. Pyati, B.M. Chittapur, A.S. Halepyati, U.K. Shanwad, S.N. Bhat and Umesh, M.R. 2017. Realization of Target Yield in Bt Cotton (Gossypium hirsutum) with Different Methods of Establishment under Varied Dates of Planting. Int.J.Curr.Microbiol.App.Sci. 6(11): 30053010. doi: https://doi.org/10.20546/ijcmas.2017.611.351 